\title{
CLIMATE VARIABILITY, ABSORPTIVE CAPACITY AND ECONOMIC PERFORMANCE IN SUB-SAHARAN AFRICA
}

\author{
Jubril Olayinka Animashaun ${ }^{1,2}$, Toyin Benedict Ajibade ${ }^{1 凶}$ \\ ${ }^{1}$ University of Ilorin, Ilorin, Nigeria \\ ${ }^{2}$ University of Manchester, United Kingdom
}

\begin{abstract}
The high reliance of Africa's GDP on agriculture makes its economic growth susceptible to climate change. The vulnerability of Africa is further worsened by the strong interlinkage that the agricultural sector has with other productive sectors. To drive policy implications that transform economic performance in Africa, it becomes important to understand the linkages between climate and economy of the region. This paper examines the effects that climate change has on economic performance in sub-Saharan African nations. Based on cross-country panel climatic data that takes account of the absorptive mechanism, it estimates the contribution of climate change to economic performance in sub-Saharan Africa (SSA). The estimator is developed based on the OLS, Fixed Effect, and the Arellano-Bond (1991) Generalized Method of Moments (GMM) estimator. The findings show that high temperature is a significant contributor to worsening economic performance in the SSA region. However, after accounting for the absorptive mechanisms, the relationship is no longer that strong. Specifically, after accounting for initial economic performance, social and political stability in the 2-stage GMM estimation, the estimate for temperature drops by $59 \%$. This result confirms the hypothesis that the negative impact of climate change in the region is not absolute, and that building an overall stable socioeconomic environment in the region could assist in buffering the impact of climate change.
\end{abstract}

Keywords: climate change, absorptive capacity, Africa

\section{INTRODUCTION}

The birth of the industrial revolution in mid-1700s led to an increase in the concentration of greenhouse gases in the atmosphere. In the last century, rapid industrialization from increased global economic activities resulted in the current increase of anthropogenic greenhouse gas emissions. Subsequently, the accumulation of greenhouse gases has been attributed to the rapid change in global temperature and precipitation (Dessalegn and Akalu, 2015).

Specifically, the temperature across the African continent is predicted to rise by $2-6^{\circ} \mathrm{C}$ over the next 100 years. Rainfall variability is predicted to grow, too, resulting in frequent flooding and droughts (Hulme et al., 2001). According to the 2007 report on Regional Climate projections from the Intergovernmental Panel on Climate Change (IPCC), average temperatures in Africa are predicted to increase by $1.5-3^{\circ} \mathrm{C}$ by 2050 , and the warming of Africa is very likely to be stronger than elsewhere around the globe (Dessalegn and Akalu, 2015).

Conceptually, climate change could affect biodiversity and subsequently food security, water availability, and productivity levels in Africa (Hope, 2009). Extreme poverty and continued rapid loss of biodiversity appear intimately related (Barrett et al., 2011). The high reliance of Africa's GDP on agriculture makes its economic growth susceptible to climate change. The vulnerability of Africa

\footnotetext{
\Toyin Benedict Ajibade, Department of Agricultural Economics and Farm Management, University of Ilorin, Nigeria PMB 1515, Ilorin, Nigeria, e-mail: ajibade.tb@unilorin.edu.ng, https://orcid.org/0000-0001-5161-7500
} 
is further worsened by the strong inter-linkage that the agricultural sector has with other productive sectors.

Over the years, several efforts have been dedicated to exploring the linkages between climate change and economic performance in low and middle-income countries (Abidoye and Odusola, 2015; Barrios et al., 2010; Bowen et al., 2012). Indeed, studies as far back as Montesquieu (1823) and Huntington (1915), observed that hot countries tend to be poorer. Nordhaus (2006) empirically verified that a strong correlation exists between heat and poverty. Despite the correlation between warming and income in sub-Saharan Africa (SSA), it is still relatively unclear whether income is a monotonic function of climate change or if other adaptive factors such as a country's institutions, trade policy or previous economic prosperity are important for moderating the effect of vagaries of climate (Dell et al., 2009).

In an earlier study, Dell et al. (2009) explore the case of adaptive capacity based on cross-country data and sub-national data at the municipal level for 12 countries in the Americas to provide cross-sectional evidence for the temperature-income relationship. The estimates suggest that, in the cross-country context, adaptation offsets about half of the negative effects of higher temperatures. They further show that the temperature effects on growth are so large that in the absence of offsetting forces, they would quickly produce a much steeper relationship than what can be observed between temperature and income (Dell et al., 2009).

This paper builds on the study by Dell et al. (2009) and explores the link between temperature and economic performance in SSA. The authors of this paper believe that the increase in temperature could not be a monotonic function of economic performance. In their approach, adaptive capacity is proxied with the initial level of economic development, socio-political disturbance and institutional quality. Also, the authors argue that African countries with a history of economic growth in the previous year(s) would most likely have a higher adaptive capacity to offset the stymieing effect of the rise in temperature.

To explore the direct role of climate in explaining the economic performance, this study used a panel regression of climate variables from the replication data of Burke's et al. (2009) influential paper that explored the link between conflict and climate change in 1981-2006 in sub-Saharan Africa. This model relates country-level fluctuations in temperature, precipitation and social and economic adaptive capacities to the economic performance of countries in the SSA region.

The estimator is developed based on the OLS, Fixed Effect and the Arellano-Bond (1991) GMM estimator. GMM takes into consideration the autocorrelation arising from the inclusion of lagged GDP (economic performance) variables and country Fixed Effects (FE) to control for heterogeneity among countries. With these estimators, the orthogonality between the time-lagged economic variables of adaptive capacities and the disturbances generates additional instruments (Gala et al., 2017).

Findings from this study provide quantitative evidence to support the hypothesis advanced by the authors. In the OLS estimation, it was found that across all model specifications, an increase in temperature (in contrast to precipitation) accounts significantly for a decline in economic performance. The Fixed Effect (FE) estimation with full controls shows a reduction in the coefficients of the effect of temperature on economic performance. Specifically, a $1 \%$ rise in average temperature for the current and previous year causes a $20 \%$ decline in GDP per capita in the model without control. However, after including the full controls and when controlling for the 1 -year lagged economic performance in the dynamic 2 -step GMM estimation, the estimates show that a $1 \%$ rise in temperature causes a decline in economic growth by just $9 \%$. This finding tends to support the hypothesis that each country has absorptive mechanisms that reduce the effect of climate change on economic performance. Also, the authors' FE model with full controls shows a positive relationship between precipitation and economic performance.

This paper concludes by recommending that policymakers in SSA adopt a holistic approach to building and strengthening the economy. There is a need for avoidance of conflict as a policy measure taken to reduce the economic impacts of climate change. The remainder of the paper is structured as follows: Section 2 presents the research methodology; Section 3 presents the results and discussion; and Section 4 is the conclusion.

\section{RESEARCH METHODOLOGY}

\section{Study area}

Geographically, sub-Saharan Africa is the area of the African continent that lies south of the Sahara. The region is often categorized as a fragile territory with higher risk and vulnerability to socioeconomic, political and 


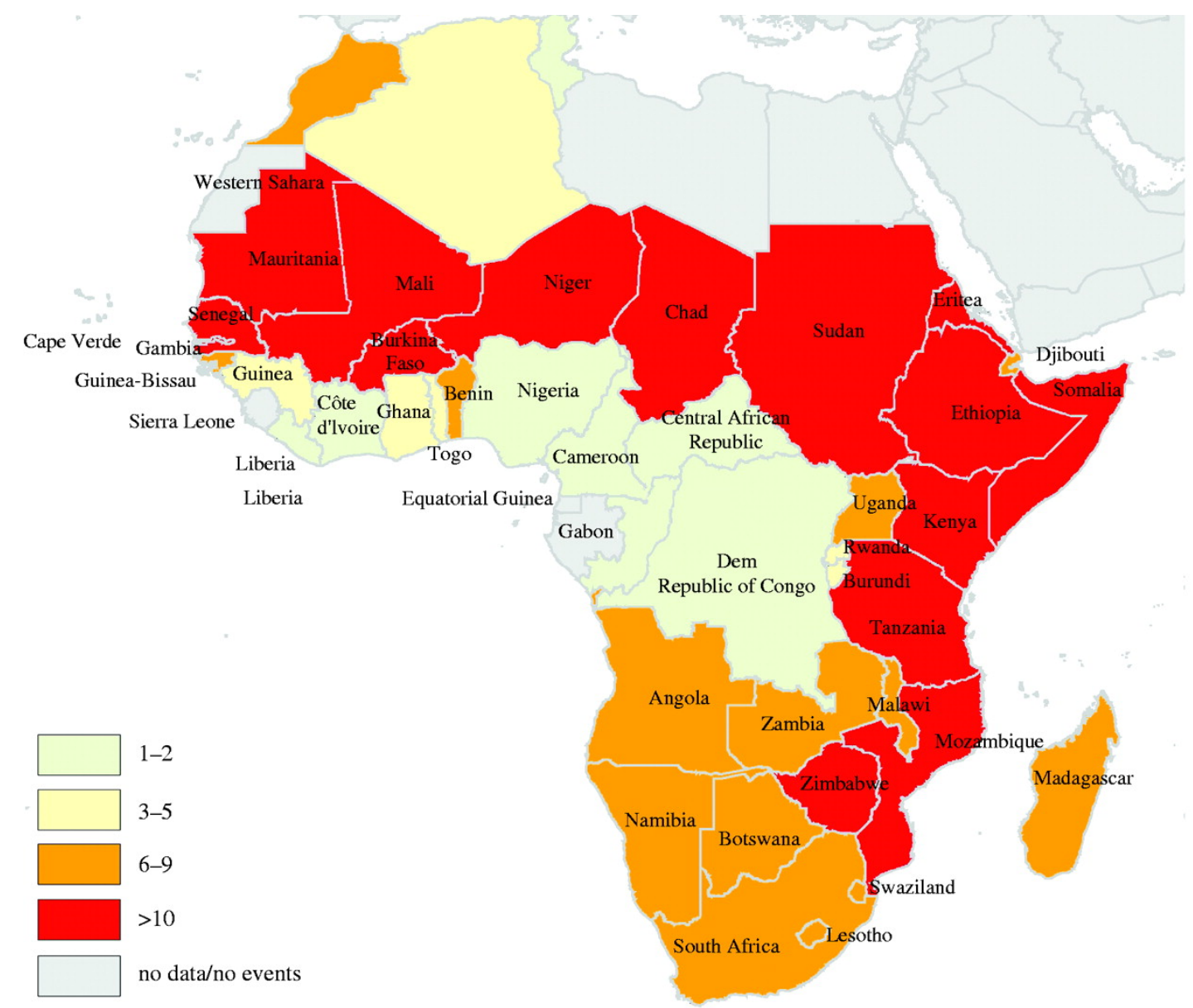

Fig. 1. Map of Africa showing the sub-Saharan states and drought vulnerability from 1970 till 2004 Source: https://ourworldindata.org/ofdacred-international-disaster-data

environmental hazards. Agriculture accounts for $20 \%$ to $30 \%$ of GDP and $50 \%$ of exports. Also, a substantial amount of local labor force (60\% to $90 \%)$ are employed in agriculture.

Climate variability and extreme weather events such as droughts, excessive rains, and floods are among the main risks affecting agricultural productivity and household income. Extreme weather, often characterized by drought, is directly linked to agricultural failure which reduces food availability at the household level and limits rural employment opportunities.

\section{Data}

The main source of data comes from the replication data of the study by Burke et al. (2009) which is freely available online through the Proceedings of the National Academy of Sciences (PNAS) open-access option. In Burke et al. (2009), the authors explain that historical climate data is derived from 3 sources. The main source is climate data from the University of East Anglia, which provides monthly minimum and maximum temperature and precipitation on a 0.5 by 0.5 -degree grid for the period 1901-2002.

As discussed in Burke et al. (2009), the second source is the National Center for Environmental Prediction/National Center for Atmospheric Research (NCC), which is available for 1948-2000 (the daily minimum and maximum is constructed from 4 daily observations). The third source of precipitation data is the Global Precipitation Climatology Project (GPCP) of NASA's 
Goddard Space Center available for 1979-2008. The authors constructed a country-level time series of average temperature and precipitation based on this data, using two different spatial and temporal averages. The first approach was by averaging climate over all grid cells in a country for a given year; that is, temperature (precipitation) was averaged over all cells, and then averaged (summed) over all of the months in a year. The second approach consisted in averaging climate data over the areas and months in which crops are grown.
The dependent variable (economic performance data) is based on levels of annual per capita income (in 1985 dollars) and was derived from the World Development Indicators and the Penn World Tables (World Bank, 2007; Heston et al., 2006). One-year lagged GDP per capita was introduced as part of control variables to account for the initial economic performance which is used as a proxy for adaptive economic capacity. Common in the literature is the plausible correlation of this variable with underdevelopment; however, the authors

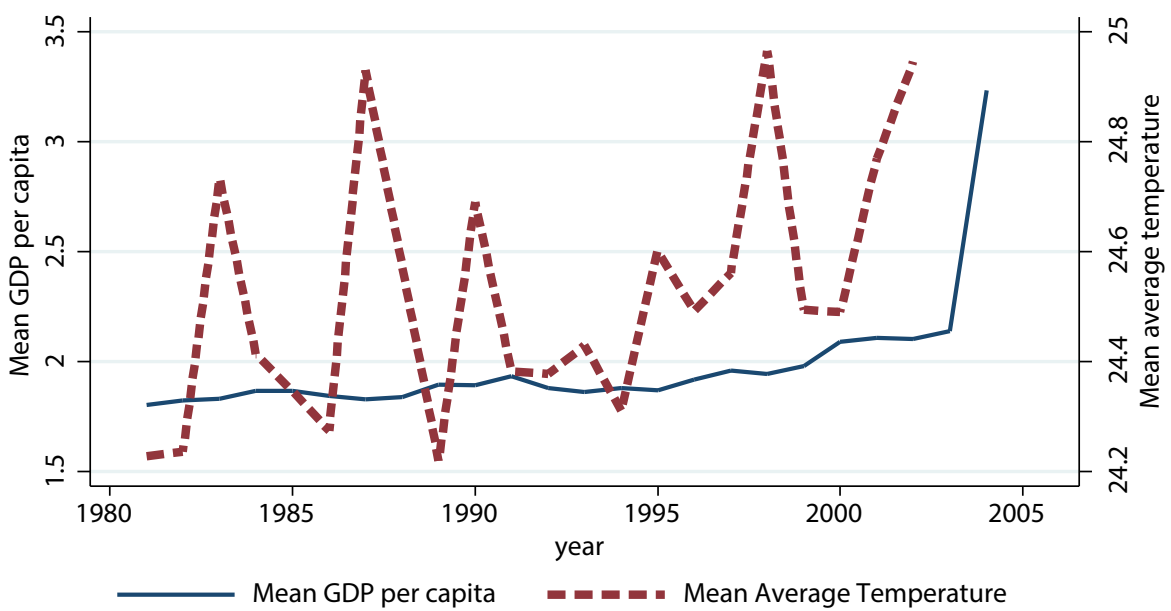

Fig. 2. Trends in GDP per capita and mean temperature in SSA

Source: own elaboration based on study data.

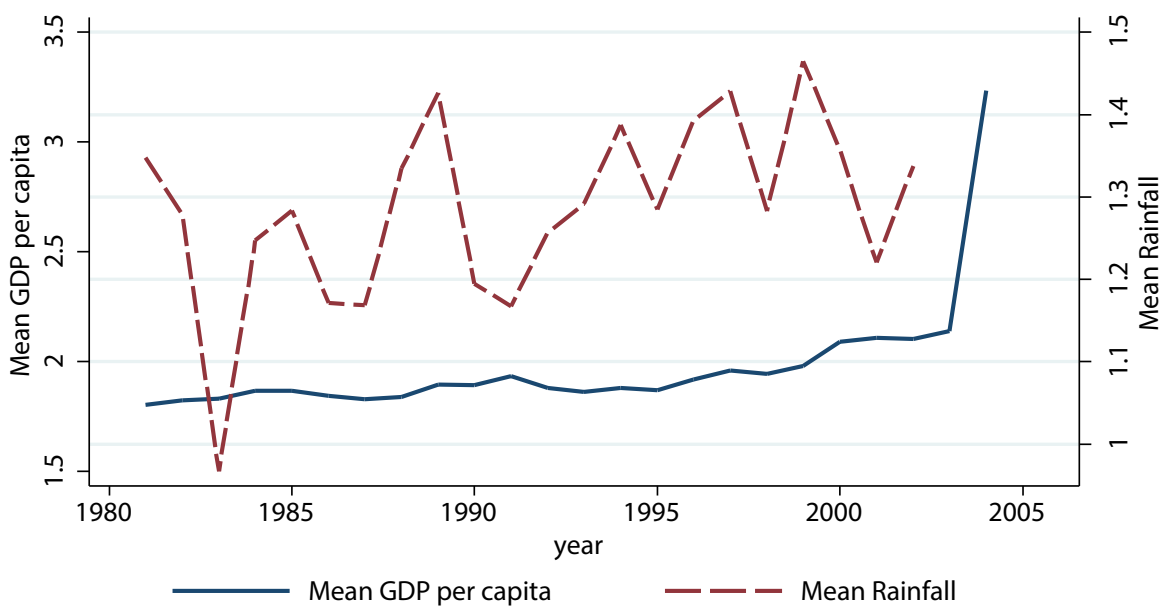

Fig. 3. Trends in GDP per capita and mean precipitation in SSA

Source: own elaboration based on study data. 
further instrument $2^{\text {nd }}, 3^{\text {rd }}$, and $4^{\text {th }}$-year lagged income in the 2-stage GMM estimators.

Data on social factors that strengthen adaptive capacity was collected by using observation on the prevalence of conflict measured as the incidence of civil war, following the research of Burke et al. (2009). According to the authors, the conflict variable comes from the Armed Conflict Data database developed by the International Peace Research Institute of Oslo, Norway, and the University of Uppsala, Sweden. Civil war is defined in the PRIO/Uppsala database as "a contested incompatibility which concerns government and territory where the use of armed force between two parties, of which at least one is the government of a state, results in at least 1000 battle-related deaths."

Data on political regime type is used to capture how political structure strengthens adaptive capacity. Data from the Polity IV database measure describes the extent to which countries are democratic. Scores are reported annually at the country level and range between -10 (full autocracy) and +10 (full democracy); this variable is lagged by one year. Democratization is an institutional quality indicator, and it is likely endogenous to income level (Acemoglu et al., 2001; Burke et al., 2009). Caution should be exercised in evaluating its effects on economic performance.

\section{Model specification}

The regression equation presented in this study builds on Burke's et al. (2009) specification. It links economic performance in country $i$ in year $t$ to various measures of historical climate, $x_{i t}$, conditional on country fixed effects and country time trends. Climate is represented by country-average temperature in the current and previous year based on CRU data. The model includes both contemporaneous and lagged climate variables. The procedure starts by exploring the effect of contemporaneous $\left(X_{i t}\right)$ and lagged temperature variables $\left(X_{i t-1}\right)$ on GDP per capita. The main specification uses annual data for the period 1981-2006:

$$
\begin{gathered}
G D P / \text { capita }_{i, t}=\alpha i+\beta 1\left(X_{i t}\right)+\beta 2\left(X_{i t-1}\right)+ \\
+\delta\left(\text { Year }_{t}\right)+\mu_{i t}
\end{gathered}
$$

In the formula above, $\alpha i$ represents country fixed effects that account for time-invariant country-specific characteristics (such as institutional capacity) that might explain differences in the baseline level of economic performance; and $\delta$ represents country time trends to be controlled for country-specific variables that could be evolving and altering national income. The baseline specification does not account for initial economic performance and does not control for any other time-varying adaptive social and political capacities.

Because this study focuses on the sub-Saharan region of Africa where agriculture is a major contributor to GDP, the effect of high temperature on agricultural yield is expected to be suppressed by regular precipitation or rainfall. In essence, with regular rainfall, it is possible for the long spell of dryness and hotness to be offset with sufficient precipitation. Therefore, the model includes variables relating to contemporaneous $\left(P_{i t}\right)$ and lagged precipitation $\left(P_{i t-1}\right)$ data from Burke et al. (2009) in equation 2 .

$$
\begin{gathered}
G D P / \text { capita }_{i, t}=\alpha i+\beta 1\left(X_{i t}\right)+\beta 2\left(X_{i t-1}\right)+ \\
+\beta 3\left(P_{i t}\right)+\beta 4\left(P_{i t-1}\right)+\delta\left(\text { Year }_{t}\right)+\mu_{i t}
\end{gathered}
$$

These two models show the estimates of the effects of climate on economic performance without controlling for time-varying social, economic and political adaptive capacities. As a further extension, this study considers a full model where the adaptive capacities are included in equation 3 .

$$
\begin{gathered}
G D P / \text { capita }_{i, t}=\alpha i+\beta 1\left(X_{i t}\right)+\beta 2\left(X_{i t-1}\right)+ \\
+\beta 3\left(P_{i t}\right)+\beta 4\left(P_{i t-1}\right)+\theta\left(W_{i t}\right)+\Psi\left(K_{i t-1}\right)+ \\
\Phi\left(M_{i t}\right)+\delta\left(\text { Year }_{t}\right)+\mu_{i t}
\end{gathered}
$$

In the above equation, the additional variables of, $W_{i t}$, $K_{i t-1}$ and, $M_{i t}$ represent the incidence of war, the lagged value of GDP/capita in year $t-1$ and annual population growth for country $i$ in time $t$.

Because of the plausible endogeneity of the 1-year lag of GDP, implying that it is also likely to be correlated with unobserved factors responsible for economic underdevelopment $\left(\mu_{i t}\right)$, the 2-Stage GMM estimation and instrument $K_{i t-1}$ are considered with the two, three and fouryear lagged values of income per capita in equation 4 .

Furthermore, if the underlying channel through which climate is supposed to affect economic performance in the SSA is agriculture, then the relationship might not be linear. The authors specify models that include non-linearity between climate and economic performance in Table 3 (Burke et al., 2009; Schlenker and Roberts, 2006). Subsequently, equation 3 is extended and estimation is as shown in equation (4): 
Table 1. Robustness analysis. Effect of current and lagged temperature and precipitation on economic performance (including quadratic climate terms)

\begin{tabular}{|c|c|c|c|c|}
\hline \multirow{2}{*}{ Variable } & \multicolumn{2}{|c|}{ Model 1 (OLS) } & \multicolumn{2}{|c|}{ Model 2 (FE 2-stage GMM) } \\
\hline & coefficient & SE & coefficient & $\mathrm{SE}$ \\
\hline Tempt $^{2}$ (average of current and previous-year values) & $-0.001 * *$ & 0.0005 & $-0.002 * *$ & 0.001 \\
\hline 1-year lagged Tempt ${ }^{2}$ & $0.001 * *$ & 0.0004 & 0.001 & 0.001 \\
\hline $\operatorname{Precipt}^{2}$ (average of current and previous-year values) & 0.01 & 0.01 & 0.004 & 0.046 \\
\hline 1-year lagged Precipt ${ }^{2}$ & $-0.02 * *$ & 0.01 & 0.001 & 0.05 \\
\hline Incidence of war & $-0.065^{* *}$ & 0.032 & $-0.06^{*}$ & 0.04 \\
\hline 1-year lagged democratization index & 0.001 & 0.003 & 0.0001 & 0.002 \\
\hline Annual population growth & 0.007 & 0.006 & -0.004 & 0.01 \\
\hline 1-year lagged per-capita income & $1.0^{* * *}$ & 0.009 & $0.824 * * *$ & 0.07 \\
\hline Observations & \multicolumn{2}{|c|}{723} & \multicolumn{2}{|c|}{621} \\
\hline
\end{tabular}

Source: own elaboration.

$$
\begin{gathered}
\text { GDP / } \text { capita }_{i, t}=\alpha i+\beta 1\left(X^{2}{ }_{i t}\right)+\beta 2\left(X^{2}{ }_{i t-1}\right)+ \\
+\beta 3\left(P^{2}{ }_{i t}\right)+\beta 4\left(P^{2}{ }_{i t-1}\right)+\theta\left(W_{i t}\right)+\Psi\left(K_{i t-1}\right)+ \\
+\Phi\left(M_{i t}\right)+\delta\left(\text { Year }_{t}\right)+\mu_{i t}
\end{gathered}
$$

$\beta_{1}$ and $\beta_{2}$ represent the estimate of quadratic terms of temperature (average of current and previous values) and 1-year lagged temperature, respectively; $\beta_{3}$ and $\beta_{4}$ represent the estimate for precipitation (average of current and previous values) and 1-year lagged values of precipitation, respectively.

$$
\begin{gathered}
K_{i t-1}=\alpha i+\Omega 1\left(Z_{i t-2}\right)+\Omega 2\left(Z_{i t-3}\right)+\Omega 3\left(Z_{i t-4}\right)+ \\
+\delta\left(\text { Year }_{t}\right)+\mu_{i t}
\end{gathered}
$$

The robustness of the identification strategy is checked by including reliability tests for the instruments used. The result of the robustness test is presented in Table 1.

There appears to be no difference in the estimates of the effects of climate on economic performance with and without the use of quadratic terms.

\section{RESULTS AND DISCUSSION}

\section{OLS main results}

Using the standard OLS, the authors first estimate equations (1) to (3) without accounting for country Fixed Effect but controlling for time dummies. Column (2) of Table 2 includes temperature variables only. This mainly is the average of the current and previous-year temperature and 1-year lagged temperature. Model (2) of the same Table (1) includes precipitation and 1-year lagged precipitation values as additional variables. As can be seen, the coefficient on temperature is significant in both models while precipitation remains insignificant. Put differently, a higher temperature would have a negative effect on income per capita in SSA countries.

The result of the effect of temperature on income per capita holds in model (3) with the inclusion of the incidence of war, democratization index and annual population growth. However, model (4) builds on previous models and has an additional 1-year lag of GDP per capita. Here, the finding is that the coefficient on temperature has dropped from 0.22 to 0.06 ; another observation is that a decline in 1-year lagged precipitation leads to a 0.06 decline in GDP per capita. Put differently: lower rainfall will have a negative effect on economic performance in SSA countries even after accounting for initial economic performance and other controls that could plausibly influence economic performance.

Both temperature and precipitation can affect agricultural yields in SSA where the vast majority of households are rural and derive their income from agricultural activities (Lobell et al., 2008; Jones and Thornton, 2003). Agriculture in the SSA is still largely natural rainfed and with little provision made for irrigation farming. African staple crop yields have been shown to reduce 
Table 2. OLS estimates of climate and economic performance

\begin{tabular}{|c|c|c|c|c|c|c|c|c|}
\hline \multirow{2}{*}{ Variables } & \multicolumn{2}{|c|}{ Model 1} & \multicolumn{2}{|c|}{ Model 2} & \multicolumn{2}{|c|}{ Model 3} & \multicolumn{2}{|c|}{ Model 4} \\
\hline & coefficient & std. err. & coefficient & std. err. & coefficient & std. err. & coefficient & std. err. \\
\hline $\begin{array}{l}\text { Tempt (average of current and previ- } \\
\text { ous-year values) }\end{array}$ & $-0.22 * *$ & 0.1 & $-0.23^{*}$ & 0.12 & $-0.21^{*}$ & 0.12 & $-0.06^{* * *}$ & 0.02 \\
\hline 1-year lagged Tempt & -0.07 & 0.05 & -0.1 & 0.06 & -0.08 & 0.07 & $0.06^{* * *}$ & 0.02 \\
\hline $\begin{array}{l}\text { Precipt (average of current and } \\
\text { previous-year values) }\end{array}$ & & & -0.07 & 0.44 & -0.04 & 0.44 & 0.05 & 0.03 \\
\hline 1-year lagged Precipt & & & -0.04 & 0.26 & -0.07 & 0.25 & $-0.09 * *$ & 0.04 \\
\hline Incidence of war & & & & & $-1.1 * * *$ & 0.44 & $-0.07 * *$ & 0.03 \\
\hline 1-year lagged democratization index & & & & & 0.008 & 0.06 & 0.001 & 0.003 \\
\hline Annual population growth & & & & & -0.16 & 0.11 & 0.01 & 0.01 \\
\hline 1-year lagged per-capita income & & & & & & & $1.0^{* * *}$ & 0.01 \\
\hline Constant & $9.3 * * *$ & 3.4 & $9.44 * * *$ & 3.72 & $9.7 * * *$ & 3.61 & 0.17 & 0.15 \\
\hline Observations & 777 & & 777 & & 723 & & 723 & \\
\hline R-sq & 0.16 & & 0.17 & & 0.17 & & 0.98 & \\
\hline RMSE & 1.9 & & 1.9 & & 1.9 & & 0.23 & \\
\hline
\end{tabular}

Model (1) to Model (4) estimate the effect of climatic variables on GDP per capita. Model (1) estimates GDP per capita as a function of average temperature in the current and previous year and in the lagged year. Model (2) includes the average of lagged and current precipitation and 1-year lagged precipitation in addition to temperature variables. Model (3) concludes the controls of incidence of war, regime type, and population growth. Model (4) includes the 1-year lagged income per capita. All models control for time dummies. Standard error is robust and clustered at country level. The coefficient represents the marginal effect of the variable on GDP per capita; asterisks $* * *$, and $* * *$ represent the significance of the coefficient at $10 \%, 5 \%$ and $1 \%$, respectively.

std. err. - standard error

Source: own elaboration.

by $10-30 \%$ per ${ }^{\circ} \mathrm{C}$ of temperature. Hence, agriculturerelated yields could have an economic impact on rural income and poverty.

In recent studies (Randall, 2007; Schlenker and Lobell, 2009) show the particular role of temperature in explaining past spatial and temporal variation in agricultural yields and economic output in Africa. Bowen et al. (2012) explain in their introduction that the combination of: (i) proximity to temperature thresholds, (ii) a higher economic sensitivity to climate events via the contribution of agriculture to GDP and (iii) a lower adaptive capacity to manage biotic and abiotic stress from climate change make low-income countries more vulnerable to global warming.

The World Bank (2013) warns that climate change will put recent development achievements at risk, unless they can be safeguarded through effective adaptation.
Development strategies must be designed to be resilient to future climate change. This must as well be implemented within a holistic framework that allows for timely action to forestall worsening of economic situation. It is particularly notable that economic development alters people's income and wealth, which is a key driver of climate vulnerability (Fankhauser et al., 2013; Fankhauser and McDermott, 2014; Bowen et al., 2016).

Findings from this study concerning the inclusion of conflict variables are in tandem with past studies (Blattman and Miguel, 2010; Collier and Hoeffler, 2004) which established a link between the two variables. It therefore appears unsurprising that the effect of incidence of war on economic performance is still noticeable as shown in Model (3) and Model (4) even after accounting for the 1-year lag of income per capita (Model 4). 
Within-country variation of the effect of climate change on economic performance Next, the OLS model estimation is extended by including country FE to further control for country-level unobservable absorptive mechanisms in Table 3. It can be suspected that even after controlling for war, political regime and initial economic progress, it is still possible for high temperature to be highly correlated with underdevelopment (which is not included in the controls). Furthermore, the level at which these unobservable economic development factors are present could either magnify or reduce the effect of climate change on economic

Table 3. FE estimates of the effect of climate change on economic performance

\begin{tabular}{|c|c|c|c|c|c|c|c|c|c|c|}
\hline \multirow[b]{2}{*}{ Variables } & \multicolumn{2}{|c|}{ Model 1} & \multicolumn{2}{|c|}{ Model 2} & \multicolumn{2}{|c|}{ Model 3} & \multicolumn{2}{|c|}{ Model 4} & \multicolumn{2}{|l|}{ Model 5} \\
\hline & $\begin{array}{l}\text { coeffi- } \\
\text { cient }\end{array}$ & std. err. & $\begin{array}{l}\text { coeffi- } \\
\text { cient }\end{array}$ & std. err. & $\begin{array}{l}\text { coeffi- } \\
\text { cient }\end{array}$ & std. err. & $\begin{array}{l}\text { coeffi- } \\
\text { cient }\end{array}$ & std. err. & $\begin{array}{l}\text { coeffi- } \\
\text { cient }\end{array}$ & std. err. \\
\hline Tempt & $-0.20 *$ & 0.11 & -0.19 & 0.11 & -0.21 & 0.13 & -0.07 & 0.04 & $-0.09 * *$ & 0.05 \\
\hline 1-year lagged Tempt & 0.03 & 0.04 & 0.04 & 0.05 & 0.02 & 0.13 & 0.07 & 0.03 & 0.07 & 0.05 \\
\hline Precipitation & & & 0.12 & 0.09 & 0.09 & 0.09 & $0.12 *$ & 0.06 & 0.09 & 0.11 \\
\hline $\begin{array}{l}\text { 1-year lagged } \\
\text { Precipitation }\end{array}$ & & & 0.12 & 0.14 & 0.08 & 0.15 & -0.01 & 0.001 & 0.03 & 0.12 \\
\hline Incidence of war & & & & & $-0.15^{* *}$ & 0.06 & $-0.06^{*}$ & 0.04 & -0.06 & 0.04 \\
\hline $\begin{array}{l}\text { 1-year lagged democra- } \\
\text { tization index }\end{array}$ & & & & & -0.05 & 0.01 & -0.001 & 0.001 & 0.0003 & 0.002 \\
\hline $\begin{array}{l}\text { Annual population } \\
\text { growth }\end{array}$ & & & & & 0.04 & 0.04 & 0.001 & 0.01 & -0.003 & 0.01 \\
\hline $\begin{array}{l}\text { 1-year lagged per-capita } \\
\text { income }\end{array}$ & & & & & & & $0.85 * * *$ & 0.08 & $0.83 * * *$ & 0.07 \\
\hline Constant & $6.4^{*}$ & 3.69 & 5.66 & 3.6 & 6.99 & 4.33 & 0.24 & 1.22 & & \\
\hline Observations & & & & & & & 72 & & & 21 \\
\hline R-sq & & & & & & & 0 . & & & 63 \\
\hline RMSE & & & & & & & & & & 0.23 \\
\hline
\end{tabular}

Panel B. Identification tests for Model 4

Under-identification test

Kleibergen-Paap rk LM statistic 24.8***

Weak identification test

Cragg-Donald Wald F-stat

Kleibergen-Paap rk Wald F statistic $\quad 50$

Over-identification test

Hansen J stat

Model 1 estimates the effect of (contemporaneous and 1-year lagged) temperature on income. In addition to temperature, model 2 includes (current and one-year lagged) precipitation. Model 3 adds additional controls of conflict, good governance and population growth. Model 4 controls for lagged within-country variation in income per capita. Model 5 uses a 2-stage GMM estimation to control the plausible endogeneity of income per capita and instruments with lagged income per capita. All models control for country and time FE. Standard error is robust and clustered at the country level. The coefficient represents the marginal effect of the variable on GDP per capita; asterisks *,**, and *** represent the significance of the coefficient at $10 \%, 5 \%$ and $1 \%$ respectively.

std. err. - standard error

Source: own elaboration. 
performance. The authors also assume that these factors could be fixed and non time-varying which makes this within-country estimation suitable for removing the bias introduced by country-level unobservable heterogeneities. The result of FE estimation in presented in Table 3.

As can be seen across the model's specification with and without full controls, the effect of temperature and rainfall on economic performance in SSA in the OLS may simply be capturing country-level unobservable heterogeneities. In model (1) of Table 3, the temperature-only model suggests a weak relationship between temperature and economic performance. However, including precipitation in the model (2) makes temperature no longer significant in explaining the variation in income per capita of SSA countries. Model (3) is extended with additional controls of conflict, political regime, and annual population growth. Again, climatic variables fail to significantly explain the differences in income per capita. Model (4) also includes the 1-year lag of income per capita to control for the initial level of economic development.

It is possible that rich countries would have the absorptive capacity to reduce the negative effect of climate on economic growth. This could be by providing additional insurance coverage to farmers or by investing in irrigation or smart agriculture targeted at minimizing the decline in income that could be associated with a decline in agricultural yield and revenue. The finding with the initial income per capita shows that SSA countries with high income per capita experience a reduced negative impact of climate change.

Indeed, while the estimate of temperature is insignificant, the estimate of precipitation is positive, suggesting that the higher the rainfall, the higher the income per capita in SSA. In this aspect, the findings corroborate Barrios et al. (2010) who concluded that rainfall has been a significant determinant of poor economic growth for SSA nations but not for other countries. However, a correlation of the 1-year lag of income per capita with underdevelopment is plausible, implying the endogeneity of the estimates. Therefore, the authors instrument the 1-year lag income with the 2-year, 3-year and 4-year lag of income per capita. The result of the test of relevance for the instruments is shown in Panel B of Table 3.

The F-stat of the Cragg-Donald test is 268 which is a considerably high level, hence suggesting that the instruments are not weak. Furthermore, instrumenting and estimating using the 2-stage GMM improves the performance of the model. The result is presented in model (5). As can be seen, the coefficient on temperature dropped from 0.20 in model (1) of Table 3 to 0.09 in model (5) but remained significant. This finding is in line with Mendelsohn et al. (1994) who used a Ricardian model to show that temperature could have a negative effect on agriculture and - given the dependence of SSA economy on agriculture - it is possible that temperature would have an impact on income per capita in this region.

According to a UNCTAD Report (2012), climate change has been demonstrated to have (and to be likely to continue to have) a huge impact in the region because of Africa's geography, its high level of dependence on agriculture, and the fact that it has a smaller adaptive capacity. Specifically, Boko et al. (2007) suggest that the projected reduction in agricultural yields in some African countries is likely to be as high as $50 \%$ by 2020 , and that net crop revenue could decline by as much as $90 \%$ by 2100 . It is also estimated that the proportion of arid and semiarid lands in the region may increase by $5-8 \%$ by 2080 .

Other studies (Boyd and Tompkins, 2009; Wheeler, 2011) also corroborate the negative impact of climate change in the African region, with Wheeler (2011) providing an estimate of the vulnerability of countries to climate change resulting from increasing weatherrelated disasters, sea-level rise, and loss of agricultural productivity. Collier, Conway and Venables (2008) have also submitted that Africa is likely to be affected more severely by climate change than other regions. IPCC (2014) suggest that a certain amount of climate change is unavoidable. This clearly indicates that it becomes important to tackle the challenge if economic performance in the region will be enhanced.

\section{CONCLUSION AND RECOMMENDATIONS}

This study explores the link between temperature and economic performance in SSA. The authors of this paper believe that the increase in temperature could not be a monotonic function of economic performance. In their approach, adaptive capacity is proxied with the initial level of economic development, socio-political disturbance and institutional quality. Also, the authors argue that African countries with a history of economic growth in the previous year(s) would most likely have 
a higher adaptive capacity to offset the stymieing effect of the rise in temperature.

To the best of the authors' knowledge, many studies linking the temperature and economic performance in sub-Saharan Africa fail to fully account for the role of adaptive capacity. Therefore, there is uncertainty in the possible estimates placed on climate change in explaining economic growth in Africa (Bowen et al., 2012). This uncertainty could confuse efforts aimed at building a more comprehensive understanding of the economic costs of climate change and at planning appropriate policy responses (Burke et al., 2009).

The estimator is developed based on the OLS, Fixed Effect and the Arellano-Bond (1991) GMM estimator. A sharp difference was observed between the OLS and FE estimation. Specifically, the sharp difference in the temperature estimates between OLS and FE models with full controls suggest a non-monotonicity in the effect of climate changes on economic performance. These findings illustrate the significant role influencing mechanisms that could trigger or dilute the effect of climate on economic performance.

Also, this study shows that the absence of war and, most importantly, being on the initial economic path of economic development make the SSA nations less susceptible to the detrimental effect of climate change on the economy. This study recommends that SSA governments ensure building a robust social and political climate necessary for the overall development of the economy to reduce the harmful effects of climate change on the welfare of the people in the region.

\section{REFERENCES}

Abidoye, B. O., Odusola, A. F. (2015). Climate Change and Economic Growth in Africa: An Econometric Analysis. J. Afr. Econ., 24(2), 277-301.

Acemoglu, D., Johnson, S., Robinson, J. A. (2001). The Colonial Origins of Comparative Development: An Empirical Investigation. Am. Econ. Rev., 91, 1369-1401.

Arellano, M., Bond, S. (1991). Some Tests of Specification for Panel Data: Monte Carlo Evidence and an Application to Employment Equations. Rev. Econ. Stud., 58(2), 277-297.

Barrett, C. B., Travis, A. J., Dasgupta, P. (2011). On biodiversity conservation and poverty traps. Proc. Nation. Acad. Sci., 108(34), 13907-13912.

Barrios, S., Bertinelli, L., Strobl, E. (2010). Trends in rainfall and economic growth in Africa: A neglected cause of the African growth tragedy. Rev. Econ. Stat., 92(2), 350-366.
Barro, R. J. (1974). Are Government Bonds Net Wealth? J. Polit. Econ., 82, 1095-1117.

Blattman, C., Miguel, E. (2010). Civil war. J. Econ. Lit., 48(1), 3-57.

Boko, M., Niang, I., Nyong, A., Vogel, C., Githeko, A., Medany, M., Osman-Elasha, B., Tabo, R., Yanda, P. (2007). Africa. Climate change 2007: Impacts, adaptation and vulnerability. In: M. L. Parry, O. F. Canziani, J. P. Palutikof, P. J. van der Linden, C. E. Hanson (Eds.), Contribution of working group II to the Fourth Assessment Report of the Intergovernmental Panel on Climate Change (pp. 433-467). Cambridge, UK: Cambridge University Press.

Bowen, A., Cochrane, S., Fankhauser, S. (2012). Climate change, adaptation and economic growth. Clim. Change, 113(2), 95-106. https://doi.org/10.1007/ s10584-011-0346-8

Bowen, A., Duffy, C., Fankhauser, S. (2016). Green growth' and the new Industrial Revolution. Policy Brief. Global Green Growth Institute.

Boyd, E., Tompkins, E. (2009). Climate change: A beginner's guide. Oxford : ONEWORLD Publications.

Bruckner, M. (2012). Climate change vulnerability and the identification of least developed countries (LDCs). The United Nations Development Policy and Analysis Division Department of Economic and Social Affairs.

Burke, M. B., Miguel, E., Satyanathd, S., Dykemae, J. A., Lobell, D. B. (2009). Warming increases the risk of civil war in Africa. Proc. Nation. Acad. Sci., 106(49), 2067020674. Retrieved from: www.pnas.org/cgi/content/ full/0907998106/DCSupplemental

Collier, P., Conway, G., Venables, T. (2008). Climate change and Africa (Summer 2008). Oxf. Rev. Econ. Policy, 24(2), 211-238.

Collier, P., Hoeffler, A. (2004). Greed and Grievance in Civil War. Oxf. Econ. Paper., 56(4), 563-595.

Dell, M., Jones, B. F., Olken, B. A. (2009). Temperature and income: reconciling new cross-sectional and panel estimates. Am. Econ. Rev. Papers Proc., 99(2), 198-204.

Dessalegn, O. G., Akalu, D. S. (2015). The impacts of climate change on African continent and the way forward. J. Ecol. Nat. Env., 7(10), 256-262. DOI: 10.5897/JENE2015.0533

Fankhauser, S., McDermott, T. (2014). Understanding the Adaptation Deficit: Why are Poor Countries more Vulnerable to Climate Events than Rich Countries? Global Env. Change, 27, 9-18.

Fankhauser, S., Ranger, N., Colmer, J., Fisher, S., Surminski, S., Stainforth, D., Williamson, A. (2013). An Independent National Adaptation Programme for England. Policy Brief. London: Grantham Research Institute on Climate Change and the Environment, London School of Economics and Political Science. 
Gala, P., Camargo, J., Magacho, G. (2017). The resource curse reloaded: revisiting the Dutch disease with economic complexity analysis. Real World Econ. Rev., 81, 118-134.

Heston, A., Robert, S., Bettina, A. (2006). Penn World Table Version 6.2. Center for International Comparisons of Production, Income, and Prices at the University of Pennsylvania.

Hope, K. R. (2009). Climate change and poverty in Africa. Int J. Sust. Dev. World Ecol., 16(6), 451-461.

Hulme, M., Doherty, R., Ngara, T., New, M., Lister, D. (2001). Africa climate change: 1900-2100. Clim. Res., 17(2), $145-168$

Huntington, E. (1915). Civilization and Climate. New Haven, CT: Yale University Press.

Jeffrey, D. S., Andrew, M. W. (1996). Sources of Slow growth in African Economies. J. Afr. Econ., 6(3), 335-376.

Jones, P., Thornton, P. K. (2003). The potential impacts of climate change on maize production in Africa and Latin America in 2055. Global Env. Change, 13, 51-59.

Lobell, D. B., Burke, M. B., Tebaldi, C., Mastrandrea, M. D., Falcon, W. P., Naylor, R. L. (2008). Prioritizing climate change adaptation needs for food security in 2030. Science, 319(5863), 607-610. DOI: 10.1126/science.1152339

Mendelsohn, R., William, D. N., Daigee, S. (1994). The Impact of Global Warming on Agriculture: A Ricardian Analysis. Am. Econ. Rev., 84(4), 753-771.

Montesquieu, Ch. de Secondat (1689-1755), 1823. The spirit of laws. London: Printed for J. Collingwood.
Nordhaus, W. D. (2006). Geography and macroeconomics: New data and new findings. Proc. Nat. Acad. Sci.,103(10), 3511-3517.

Randall, D. A. (2007). Climate models and their evaluation. Climate Change 2007: The Physical Science Basis. Contribution of Working Group I to the Fourth Assessment Report of the Intergovernmental Panel on Climate Change. Cambridge, UK: Cambridge Univ. Press.

Schlenker, W., Lobell, D. B. (2009). Robust and potential severe impacts of climate change on African agriculture. Working paper. Program on Food Security and Environment, Stanford University.

Schlenker, W, Roberts, M. J. (2006). Nonlinear effects of weather on corn yields. Rev. Agric. Econ., 28, 391-398.

UNCTAD (2012). Economic Development in Africa Report: Structural Transformation and Sustainable Development in Africa. United Nations Conference on Trade and Development Publication. https://unctad.org/en/ PublicationsLibrary/aldcafrica2012_embargo_en.pdf

Wheeler, D. (2011). Quantifying vulnerability to climate change: Implications for adaptation assistance. Center for Global Development. Working Paper No. 240. Washington D.C.

World Bank (2007). World Development Indicators. Washington: World Bank.

World Bank (2013). Turn Up the Heat. Climate Extremes, Regional Impacts, and the Case for Resilience. Washington DC: World Bank. 